\title{
POVELJEVANJE Z NAMERO IN SLOVENSKA VOJSKA
}

\section{AUFTRAGSTAKTIK - MISSION COMMAND IN THE SLOVENIAN ARMED FORCES}

Povzetek Besedilo obravnava doktrino in načela poveljevanja $\mathrm{z}$ namero, njegov izvor in temeljne pogoje za njegovo delovanje. Glede na to, da je bila doktrina poveljevanja z namero razvita konec 19. stoletja, članek v nadaljevanju opredeli nekatere družbene, tehnološke in vojaškostrokovne dejavnike, ki so bistveni za uveljavitev poveljevanja $\mathrm{z}$ namero, so se pa od nastanka doktrine do danes precej spremenili. Nazadnje spregovori tudi o smiselnosti uveljavitve te doktrine v Slovensko vojsko in čemu bi bilo treba ob njenem uveljavljanju nameniti posebno pozornost.

Ključne Poveljevanje z, namero, vodenje in poveljevanje, Slovenska vojska, civilno-vojaški besede odnosi, vojaško izobraževanje, vojaška tehnologija.

Abstract The text deals with the doctrine and principles of mission command, its origin and basic precondition for its functioning. Given that the doctrine of mission command, developed in the late 19th century article goes on to identify some of the social, technological, and military technical factors that are essential for the implementation of mission command, but have, since the creation of the doctrine, changed significantly. Finally, it speaks about the reasonableness of the entry into force of such a doctrine in the Slovenian army and what should be given special attention in the enforcement of the doctrine.

Key words Mission command/auftragstaktik, command and control, Slovenian Armed Forces, civil military relations, military education, military technology. 
Uvod Konec sedemdesetih in v osemdesetih letih prejšnjega stoletja so se tri različne zahodne vojske znašle $\mathrm{v}$ precej podobnem položaju. Vojska ZDA in Britanske oborožene sile v Evropi ter Izraelske obrambne sile na Bližnjem vzhodu so se znašle v situaciji, v kateri so bile soočene s številčno in tehnološko močnejšim nasprotnikom. $\mathrm{V}$ teh razmerah so začele intenzivno iskati rešitve za položaj, v katerem so se znašle. Iskale so koncepte, s katerimi bi lahko nevtralizirale svoje pomanjkljivosti in dosegle prevlado na bojišču. Vse tri so se ozrle v zgodovino in "ponovno odkrile« pruskonemško doktrino auftragstaktik.

Principi auftragstaktik so plod prusko-nemške vojaške šole pod vodstvom Helmuta von Moltkeja (starejšega). Angleško govoreči svet je auftragstaktik prevedel v mission command, stotnik Miha Rijavec pa je za uporabo v Slovenski vojski (SV) predlagal izraz poveljevanje z namero (Rijavec, 2012, str. 34). Doktrina SV sicer uporablja izraz poveljevanje na podlagi poslanstva, vendar menim, da je poveljevanje z namero bližje prusko-nemškemu auftragstaktik kot anglo-ameriški mission command in da ustrezno povzema bistvo nemškega pojmovanja.

Trdim, da je poveljevanje z namero primerno za majhne in tehnološko slabše razvite vojske, kakršna je tudi SV. Najprej je treba opredeliti njegov koncept oziroma vsebino in obliko, kot je bilo izvirno mišljeno. To je namreč nujno, če želimo razumeti, kako tako poveljevanje deluje, zakaj je uspešno in kaj je treba, da deluje tako, kot je zamišljeno. $\mathrm{V}$ nadaljevanju bom poveljevanje $\mathrm{z}$ namero osvetlil $\mathrm{z}$ vidika civilnovojaških odnosov, tehnologije ter sistema izobraževanja, usposabljanja in kariernih poti častniškega zbora. Nazadnje bom pogledal na poveljevanje z namero z vidika odnosa do SV.

\section{AUFTRAGSTAKTIK}

Doktrina auftragstaktik je nastala v specifičnem prusko-nemškem okolju ob koncu 19. in na začetku 20. stoletja kot posledica uničujočega pruskega poraza pri Jeni in Auerstedtu leta 1806. S francosko revolucijo so vojske postale množične, s pojavom repetirk in učinkovitega topništva pa je postalo jasno, da je treba vojsko na bojišču razpršiti (Parker, 2009, str. 200-204). Poveljujoči, če niso bili ravno vojaški geniji tipa Napoleon, niso bili več sposobni neposrednega nadzora nad podrejenimi in njihovega usmerjanja po bojišču. Od nižjih častnikov (do majorja) se je do tega trenutka pričakovalo, da bodo čim dosledneje izvrševali ukaze. Razmišljanje in sprejemanje odločitev sta bili rezervirani za višje ravni, za tiste, ki so poveljevali vsem enotam na bojišču in so običajno na njem zasedali točko, od koder so lahko opazovali vse enote in jim dajali neposredna navodila. Prusi so v vojni z Avstrijskim cesarstvom leta 1866 in Francijo leta 1871 ugotovili, da potrebujejo nov tip poveljujočih na vseh ravneh, in sicer poveljujoče, ki so sposobni presoditi situacijo in sprejeti ustrezne odločitve, tudi če nimajo neposrednih navodil in niso pod neposrednim fizičnim nadzorom nadrejenega. Težava pri tem je seveda $\mathrm{v}$ tem, kako zagotoviti ustrezna nadzor in sinhronizacijo delovanja, da ne bi podrejeni nenadzorovano 
prevzemali pobude, kar bi vodilo v kaos. Odgovor je bil v ustreznem izobraževanju poveljujočih, zagotavljanju skupne doktrine in jezika vodenja in poveljevanja ter $\mathrm{v}$ stvarnem urjenju. Skratka, v tem, da se podrejenim pove, kaj je treba storiti, in jim prepustiti, kako bodo to uresničili. To naj bi ustvarilo poveljujoče, ki bodo sposobni samostojnega kritičnega razmišljanja (Nelsen, 1987, str. 22-23). Hkrati se je pokazalo kot nujno, da so poveljujoči izbrani glede na njihove sposobnosti in ne na njihov družbeni status. Do leta 1914 je koncept v nemški vojski dokončno zaživel.

Ko govorimo o uvedbi auftragstaktik v doktrino sodobnih zahodnih oboroženih sil, moramo upoštevati, da so se civilno-vojaški odnosi, kulturno okolje, tehnologija ter izobraževanje in usposabljanje od konca prve svetovne vojne do danes precej spremenili.

Auftragstaktik je posebna doktrina vodenja in poveljevanja oboroženih sil. Njeno bistvo je v posebnem pogledu na vojno, ki jo vidijo kot spopad volj, v katerem ni nič vnaprej zagotovljeno. Grajena je na izdajanju kratkih in jasnih ukazov, ki temeljijo na poznavanju doktrine, skupnem jeziku in medsebojnem zaupanju nadrejenih in podrejenih. Ti ukazi podrejenim dovoljujejo maksimalno svobodo odločanja in pobudo znotraj omejitev dodeljene naloge in predvsem namere nadrejenega. Napake podrejenih in celo neizvrševanje naloge so dovoljeni, dokler podrejeni uspešno sledi nameri nadrejenega.

Načela auftragstaktik oziroma poveljevanja z namero temeljijo na predpostavkah, kot so:

- podrejeni razume namero nadrejenega in ji sledi ter razume morebitno trenje (frikcijo) s svojo nalogo;

- medsebojno zaupanje, ki temelji na profesionalnih kompetencah (ne pa na osebnih odnosih in poznanstvih);

- odlično komuniciranje, temelječe na skupnem razumevanju doktrine;

- visok status izobraževanja in usposabljanja;

- strpnost do tako imenovanih dobronamernih napak;

- nagnjenost $\mathrm{k}$ akciji in pobudam, samoiniciativnost;

- povezanost odgovornosti z iniciativo;

- zaupanje v to, da so posamezniki sposobni sprejemati prave odločitve.

Da bi razumeli načela poveljevanja z namero, je treba vedeti, kako je pruska oziroma nemška vojska pristopila k vojni in zgornjim načelom. Prvi in glavni imperativ v vojni, ki se pojavlja skozi ves priročnik za vodenje enot nemške vojske v drugi svetovni vojni, je hitrost, tako na strateški kot na taktični ravni (Condell, 2009). Na strateški ravni je imela Nemčija težavo dveh front. Glavna zamisel je bila nasprotnika na eni fronti vreči iz boja, še preden bi bil na drugi pripravljen na vojno. Na taktični ravni pa gre za to, da je nasprotnik po začetnem stiku s serijo hitrih manevrov postavljen v položaj, ko se je prisiljen predvsem odzvati na nemške akcije, kar naj bi omogočilo njegov poraz po delih (Nelsen, 1987, str. 23). 


\begin{tabular}{|c|c|c|}
\hline \multirow{9}{*}{$\begin{array}{r}\text { Preglednica 1: } \\
\text { Primerjava } \\
\text { glavnih } \\
\text { značilnosti } \\
\text { poveljevanja } \\
\text { z namero in } \\
\text { direktivnega } \\
\text { poveljevanja } \\
\text { kot njegove } \\
\text { alternative }\end{array}$} & Poveljevanje z namero & Direktivno poveljevanje \\
\hline & nadrejeni poveljuje z namero & nadrejeni poveljuje s podrobnimi navodili \\
\hline & medsebojno profesionalno zaupanje & nadrejeni ne zaupa podrejenim \\
\hline & jasna doktrina & jasna doktrina \\
\hline & izobraževanje, ki temelji na kritičnem razmišljanju & izobraževanje, ki temelji na izpolnjevanju nalog \\
\hline & strpnost do napak & napake niso dovoljene \\
\hline & nagnjenost $k$ pobudi in akciji & čakanje na navodila nadrejenega \\
\hline & prevzemanje odgovornosti & izogibanje odgovornosti \\
\hline & podrejeni so vredni zaupanja & podrejeni izvršujejo dobljene naloge \\
\hline
\end{tabular}

Drugo je prepričanje, da je v vojni kakršno koli podrobno načrtovanje po prvem stiku $\mathrm{z}$ nasprotnikom nesmiselno. Pri tem so sledili Moltkejevi dikciji, da »noben plan operacije ne zagotavlja zmage po prvem stiku z nasprotnikovo glavnino« (Nelsen, 1987, str. 23). Ker je vojna predvsem spopad volje, je nemogoče pričakovati, da se bo nasprotnik odzval tako, kot želimo. Ob tem pa so v nemški vojski še dobro razumeli pomen frikcije $\mathrm{v}$ vojni.

Tretji imperativ pa je bil, da so vsako situacijo v vojni obravnavali kot povsem unikatno, kar zahteva od poveljujočih, da so sposobni presoditi situacijo in hitro sprejeti odločitve ter jih nato agresivno izvesti. Ob tem je treba upoštevati še, da so odločitve morali sprejemati na podlagi nepopolnih, napačnih ali nasprotujočih si informacij (Nelsen, 1987, str. 23). Poveljujoči je zato moral biti razmišljujoči posameznik, sposoben intuicije, hitrega logičnega sklepanja in kritičnega razmišljanja, da je lahko razvil ustrezno varianto delovanja. To povzema tudi prva točka priročnika, ki pravi: »Vojna je umetnost, prosta in kreativna dejavnost, osnovana na znanstvenih principih. Do človekove osebnosti postavlja izjemno visoke zahteve.« (Condell, 2009, str. 17)

Ravno ti pogledi na vojno so tisti, ki naj bi nižje podrejenim omogočali pobudo in dali podlago za ustrezen značaj poveljujočega, solidno metodologijo izdajanja in izvrševanja ukazov ter ustrezne odnose med nadrejenimi in podrejenimi.

Značaj poveljujočega se je v nemški doktrini kazal v pripravljenosti prevzemati pobudo, v priročniku je posebej izpostavljeno, da je najbolj zaželena kakovost častnika, da je sposoben prevzemati odgovornost. Temu je treba dodati še tveganje in odločno ukrepanje. Glede na to, da so vse akcije v vojni nepredvidljive in posebne, naj ne bi iskali popolne rešitve, temveč kakršno koli teoretično rešitev, ki bi jo tudi agresivno izvedli. Častnike so posebej svarili pred tem, da bi predolgo čakali na informacije, $v$ tem oziru je bila hitrost pomembnejša od točnosti. Takoj uresničen dober načrt je bil boljši od popolnega načrta pozneje (Nelsen, 1987, str. 24). 
Nemci so leta 1988 uvedli metodologijo izdajanja ukazov, po kateri je bilo podrejenim predvsem povedano, kaj morajo storiti, ne da bi jim povedali, kako to storiti. Hkrati pa je nadrejeni podrejenemu dodelil ustrezne vire, navedel omejitve in podal navodila za usklajevanje. Smisel je bil v tem, da je bilo podrejenemu prepuščene kar največ pobude. Nemci so menili, da se bodo tako usposobljeni poveljujoči $\mathrm{v}$ vojni lažje spopadali z Clausewitzevo meglo vojne in frikcijo. Najpomembnejši del te metodologije pa ni bila izjava o poslanstvu podrejenega, temveč namera nadrejenega. Namera je bila namreč tista, ki je dala celotni operaciji nekakšno vizijo zaželenega končnega stanja. Predvsem pa je omogočala podrejenim, ki so se soočali z nepredvidenimi situacijami, da so prilagodili svoje delovanje. V najbolj skrajnih primerih je bilo celo dopustno neizvrševanje dodeljene naloge, če je podrejeni vseeno sledil nameri nadrejenega. To so bile seveda izjemne situacije in pričakovalo se je, da podrejeni v želji po odmiku od dodeljene naloge dobi potrditev nadrejenega, če pa to ni bilo mogoče, je moral svoje odločitve vedno zagovarjati po izvršenem dejstvu. Ta metodologija izdajanja ukazov pa vseeno ni pomenila, da je bil nadrejeni odsoten z bojišča. Nasprotno. Nadrejeni so vedno težili k temu, da bi bili čim bližje bojišču, a hkrati v poziciji, da so lahko vplivali na potek dogodkov. Podrejene so redno obiskovali in nadzorovali, a so v odločitve posegali le, ko je bilo to nujno ali pa je bila odločitev podrejenega očitno nespametna. Prav tako ni bilo nenavadno, če so dodali, spremenili ali prekinili naloge, dodeljene podrejenim, pač skladno s situacijo, kot so jo videli (Nelsen, 1987, str. 25).

$\mathrm{V}$ odnosih med nadrejenim in podrejenim je bil pomemben razvoj podrejenega, predvsem želenih osebnostnih značilnosti in vodstvenih sposobnosti. Pomembno ni bilo toliko, o čem podrejeni razmišlja, temveč to, kako razmišlja. Temu so bile namenjene številne aktivnosti, od taktičnih vaj na zemljevidu ali maketi do štabnih izvidovanj in terenskih taktičnih vaj. Žarišče taktičnih vaj ni bilo v taktičnem problemu, temveč $\mathrm{v}$ razvoju podrejenih. Rezultat te velike pozornosti, ki so jo nadrejeni namenjali podrejenim, je bil, da so drug drugega zelo dobro poznali. Podrejenemu je to omogočalo, da je »bral med vrsticami« ukaze nadrejenega, nadrejenemu pa, da je precej dobro vedel, kaj lahko pričakuje od podrejenega. To je seveda povzročilo obojestransko zaupanje in omogočalo uresničevanje pobud v okviru namere. Poleg tega so tako v vojaških šolah kot v enotah izpostavljali enoten pogled na naravo vojne, pobudo, želene lastnosti poveljujočega, odnos med nadrejenimi in podrejenimi ter na to, kako se izdajajo ukazi. Terminologija je bila poenotena, točno določena in široko razumljena. Tudi pristopi k reševanju problemov in $\mathrm{v}$ analizam opravljenih akcij so prispevali k pobudi in prevzemanju odgovornosti. Glede na to, da je bila vsaka situacija v vojni šteta kot enkratna in neponovljiva, ni bilo šolskih »pravilnih« rešitev. Prva rešitev je bila prav tako dobra kot druga. Kritika se je osredotočala na razmišljanje podrejenega - zakaj se je odločil tako, kot se je, katere dejavnike je pri tem upošteval in katerih ne, je izvedba ustrezala oceni, kako razumljivi so bili ukazi, ali je bila akcija taktično sprejemljiva in ali je imela resnične možnosti za uspeh. To so bila glavna vprašanja, okrog katerih se je vrtela analiza dogajanja. Cilj je bil razviti analitične sposobnosti podrejenega. Analize so bile prizanesljive in razumevajoče, ne ostre in boleče, namenjene so bile 
spodbujanju in razvoju samozavesti podrejenega. Napake so bile del procesa učenja in merilo uspeha ni bila uspešno ali neuspešno opravljena naloga, temveč koliko je posameznik pri tem napredoval (Nelsen, 1987, str. 26).

Iz zapisanega je torej jasno, da auftragstaktik ni samo tehnika pisanja ukazov, v katerih bi imela naloga osrednjo vlogo. Je precej več kot to. Je koncept, ki holistično zaobseže tako teorijo o naravi vojne kot značaj in voditeljske sposobnosti poveljujočih, taktiko, poveljevanje in kontrolo, odnos med nadrejenimi in podrejenimi ter usposabljanje in izobraževanje.

Eitan Shamir v svoji knjigi Transforming Command ugotavlja, da zaradi različnih vzrokov nobeni od zahodnih vojsk, omenjenih na začetku, ni uspelo v celoti uveljaviti doktrine auftragstaktik, kot je bila zamišljena v prusko-nemškem okolju ob koncu 19. stoletja. Razlogi za to so različni, povezani pa so s civilno-vojaškimi odnosi, tehnologijo ter sistemom izobraževanja in usposabljanja častniškega zbora.

\section{POVELJEVANJE Z NAMERO V RAZLIČNIH TIPIH OPERACIJ}

Poveljevanje z namero, kot se je oblikovalo v posebnih prusko-nemških okoliščinah, je v bistvu namenjeno poveljevanju velikim vojaškim enotam na operativni in taktični ravni, v okoliščinah manevrskega vojskovanja in brez večjih družbenopolitičnih omejitev. Poveljevanje z namero sicer ni predpogoj za manevrsko vojskovanje ali združeno bojevanje rodov, kar je dokazala že Rdeča armada med drugo svetovno vojno, je pa doktrina in sistem vodenja in poveljevanja, ki omogoča številčno in materialno šibkejšim oboroženim silam »konkurenčnost« na bojišču. Poveljevanje z namero namreč skozi načela iniciativnosti, samostojnosti in napadalnosti, ki jih dopušča, omogoča lastnim silam vstop v nasprotnikov cikel odločanja oziroma tako imenovani OODA loop ${ }^{1}$.

To pa seveda ne pomeni, da je poveljevanje $\mathrm{z}$ namero neuporabno $\mathrm{v}$ operacijah $\mathrm{v}$ podporo miru ali protiuporniških operacijah. Nasprotno, kot sistem in doktrina je ravno tako uporabno v operacijah v podporo miru in protiuporniškem delovanju kot v klasičnem manevrskem vojskovanju. Njegova načela so aplikativna tudi v prvih dveh primerih, pri čemer pa se morajo tako nadrejeni kot predvsem podrejeni zavedati posebnih okoliščin, ki jih ta dva tipa operacij prinašata, in v tem kontekstu tega, kdaj delovati, predvsem pa, kdaj ne delovati. V vseh treh tipih operacij poveljevanje $\mathrm{z}$ namero od podrejenih zahteva sledenje nameri nadrejenega, ki bo bistveno vplivala na način izvedbe dodeljene naloge. Na nadrejenem pa je, da skladno s tipom operacije svojo namero jasno, razumljivo in nedvoumno oblikuje.

Dejstvo je tudi, da je poveljevanje z namero v sodobnih zahodnih družbah postavljeno v okolje, ki zahteva številne omejitve zunaj profesionalnih in strokovnih okvirov. To okolje v marsičem vpliva na učinkovitost sistema poveljevanja $\mathrm{z}$ namero in $\mathrm{mu} \mathrm{V}$

OODA loop (Observe, Orient, Decide, Act) je metoda, ki jo je razvil polkovnik John Boyd USAF in pomeni, da bo zmagal tisti, ki v prostoru prej opazi, se pravilno orientira in odloči ter na podlagi tega prvi tudi napade. 
nekaterih primerih celo odkrito nasprotuje. Omejitve lahko razvrstimo v tri splošne kategorije civilno-vojaških odnosov, tehnologije in izobraževanja, usposabljanja ter kadrovske politike.

\section{CIVILNO-VOJAŠKI ODNOSI IN POVELJEVANJE Z NAMERO}

Socialno, politično in kulturno okolje zahodne civilizacije so se od konca 19. stoletja do danes močno spremenila. Danes govorimo o postmoderni družbi in s tem o postmodernih oboroženih silah. Najverjetnejša grožnja državi v tej družbi bodo še dolgo različna revolucionarno-teroristična gibanja (Moskos v Bebler, 2005, str. 316). Ob tem pa ne smemo pozabiti, da tradicionalne in moderne grožnje še vedno obstajajo. Je pa v postmoderni družbi prevladujoča težnja zamegljevanja mej med vojaško in civilno sfero, tako v strukturi kot kulturi (Moskos, 2000, str. 11).

Družba je od začetka 20. stoletja postala precej bolj individualizirana, materialno usmerjena in demokratična. Vrednote, kot so razumevanje s partnerjem, ljubezen, samoizpolnjevanje, zabava, vznemirljivo življenje, družabnost, dober poklic, individualnost, svoboda, ugled in napredek ${ }^{2}$ (Banko, 2009, str. 50), so med mladimi postale pomembnejše od domoljubja, predanosti, časti, lojalnosti, poguma in tovarištva ${ }^{3}$ (Furlan, 2006, str. 17), pravice pomembnejše od dolžnosti. To je hkrati povzročilo, da so zahodne družbe postale občutljive na človeške izgube, ne samo med civilnim prebivalstvom, temveč tudi znotraj vojaških organizacij. Po eni strani naj bi bile družbe boj občutljive na žrtve zaradi sprememb v vrednotah in kulturi, po drugi pa še vedno pripravljene nanje, če sta izpolnjena dva pogoja, da je ogrožen nacionalni interes in obstaja velika verjetnost zmage. Moskos pa trdi, da so družbe pripravljene sprejemati žrtve v oboroženih spopadih le, če je prebivalstvo prepričano, da so na žrtve pripravljeni tudi voditelji. Hkrati pa ugotavlja, da v zahodnih družbah (EU in Severna Amerika) te pripravljenosti voditeljev, da bi oni ali njihovi potomci služili v oboroženih silah, ni več (Moskos v Bebler, 2006, str. 321).

Vojaška organizacija je hkrati postala bistveno bolj izpostavljena civilnemu nadzoru in vedno težje uveljavlja svoje posebne interese, ki izhajajo iz narave njenega dela. Vojska ni več avtonomna, ampak je za izvrševanje svojih nalog in način, na katerega so izvršene, postala odgovorna civilni družbi (Dandeker v Moskos, 2000, str. 38). Vse skupaj pri poveljujočih povzroča odpor do odločnega in napadalnega delovanja zaradi strahu pred »nepotrebnimi« žrtvami in odzivi civilne družbe.

Bojevniški etos je postal podrejen izogibanju nevarnostim, uveljavljanju pravic posameznika in drugim omejitvam, ki so rezultat sprememb v družbi kot celoti. Družba je namreč postala izrazito nestrpna do napak, sploh če te nastajajo $\mathrm{v}$ okoliščinah, ki jih družba slabo ali malo pozna. Civilisti pa slabo poznajo vojaške zadeve in njihovo pomembnost (Dandeker v Moskos, 2000, str. 45). Vojaki tako

\footnotetext{
Vrednote mladih danes.

3 Vrednote $S V$.
} 
pogosto v bran svojemu delovanju oziroma nedelovanju izjavljajo, da »za to pa nismo usposobljeni«, kot da je vojna ali krizna situacija nekaj, kar je predvidljivo.

Zadeve, ki so bile v preteklosti interna stvar vojaške organizacije in so se reševale znotraj nje in po njenih posebnih pravilih, so zdaj izpostavljene odkriti zunanji (civilni) preiskavi. Ob tem, da je vojaško osebje v celoti podrejeno civilni zakonodaji, ki pa običajno ne pozna in ne upošteva posebnosti vojaške organizacije in okolja njenega delovanja, kar precej omejuje pripravljenost na prevzemanje pobude in akcijo ter onemogoča strpnost do »dobronamernih napak«.

SV ima, kot ugotavlja Bebler, še dodatno težavo, saj civilno-vojaški odnosi niso zdravo razviti. Kot pravi, temeljijo zdravi odnosi na 1) koherentnem in učinkovitem sistemu norm in institucij za upravljanje civilno-vojaških odnosov; 2) na kompetentnem, odgovornem in »čistem《 političnem vodstvu; 3) na predanosti, lojalnosti, profesionalni kompetentnosti, civilnem pogumu in precejšnji notranji institucionalni avtonomiji vojske; 4) na zadovoljivem javnem interesu in podpori oboroženim silam. Civilno-vojaški odnosi v Sloveniji so pomanjkljivi v vseh štirih elementih (Bebler, 2005, str. 99).

\section{IZOBRAŽEVANJE, USPOSABLJANJE TER KADROVSKA POLITIKA IN POVELEVANJE Z NAMERO}

Uspešna uvedba poveljevanja z namero v vojaško organizacijo temelji na ustreznem sistemu izobraževanja in usposabljanja ter s tem povezano kadrovsko politiko, ki ustvarja profesionalni častniški kader. Kot ugotavlja Bebler, ima SV na tej točki težavo, saj ni imela svoje tradicije profesionalnega častniškega zbora. Profesionalni častniki slovenskega porekla v JLA, predvsem višji častniki, po osamosvojitvi niso bili dovolj vključeni v nastajajočo novo strukturo. Deloma zato, ker jih preprosto ni bilo ali pa so ostali tam, kjer so si ustvarili družine. Žal je ta manko vojska na hitro zapolnila s številnimi civilisti brez ustreznih poklicnih kvalifikacij in znanja (Bebler, 2005, str. 99).

Usposabljanje $\mathrm{z}$ urjenjem $\mathrm{v}$ profesionalni organizaciji skozi dril prinaša občutek pripravljenosti, ponos in samozavest ter krepi občutek pripadnosti skupini $\mathrm{s}$ posebnimi veščinami. Izobraževanje, predvsem častnikov, pa mora poskrbeti tudi za razumevanje doktrine in načel ${ }^{4}$ vojskovanja ter enotni jezik vojaške komunikacije, s čimer častnike usposobi za pravilno razumevanje namere nadrejenega. Vse to je mogoče le, če sistem vojaškega izobraževanja in usposabljanja dovoljuje in spodbuja kritično razmišljanje 5 . Brez posameznikov, ki so sposobni kritičnega razmišljanja, ni poveljevanja z namero. Da pa bi izobraževalni sistem te posameznike ustvaril, mora

\footnotetext{
Načel in ne pravil. Doktrina mora govoriti predvsem o načelih in ne pravilih, ki naj bi jih upoštevali.

O tem, kaj točno je kritično razmišljanje, ni enotne definicije. Te se zelo razlikujejo glede na področje, ki ga avtorji obravnavajo. Voboroženih silah pa gre za to, da je posameznik v stresnih situacijah sposoben treznega razmišljanja, presoje na podlagi konfliktnih informacij, hitre sinteze dejstev, ocene možnih variant, sprejmanja odločitve, jasne kominikacije in domišljije v okviru doktrinarnih referenc.
} 
izpolniti nekaj pogojev, in sicer: 1) kulturo organizacije, ki podpira poveljevanje z namero, 2) selektivni dostop do tečajev oziroma šol (ne vsi, le tisti, ki si to zaslužijo) in, kar je najpomembnejše, 3) kompetentne inštruktorje, ki so hkrati dobri učitelji (Murray, 2014, str. 10-12).

Tečaji oziroma šole $\mathrm{v}$ sistemu izobraževanja in usposabljanja morajo podrejene usposobiti tudi za prevzemanje nalog prvonadrejenih. Poveljevanje z namero namreč predpostavlja sposobnost prevzemanja nalog nadrejenega (če je treba), predvsem pa s poznavanjem njegovih nalog omogočimo lažje razumevanje njegovih namer.

Izobraževanje mora častnike opremiti z znanjem o procedurah in orodjih za delo na štabni ravni. Pri tem pa mora v njih vzbuditi zavedanje, da procedure in orodja niso sami sebi namen in ni dobro vztrajati pri njih na škodo izpolnitve naloge, saj so zgolj pripomočki, ki olajšajo delo in služijo sinhronizaciji velikih štabnih timov. Izvrševanje naloge oziroma uresničevanje namere nadrejenega ima vedno prednost pred sledenjem proceduram.

Z izobraževanjem morajo častniki pridobiti znanje o tem, kaj je namera nadrejenega, kaj jo sestavlja in kako jo pravilno oblikovati. Častniki morajo biti sposobni sprejemati odločitve v kriznih situacijah in jih uresničevati nasprotniku navkljub ter razmišljati holistično, kar je pomembno predvsem v operacijah v podporo miru in protiuporniških operacijah.

V kombinaciji z ustrezno vsebino sistema izobraževanja in usposabljanja pa mora kadrovska politika $\mathrm{v}$ podpori poveljevanju $\mathrm{z}$ namero zagotoviti promocijo in stimulacijo najboljših in predvsem izločitev neprimernih posameznikov oziroma tistih, ki sistemu škodijo. To dosežemo s kadrovskim sistemom, v katerem so nagrade in sankcije jasno opredeljene in v funkciji podpore želenemu ravnanju (Vandergriff, 2011, str. 12). Poveljevanje z namero ima jasno opredeljeno želeno ravnanje: pobudo, prilagodljivost, napadalnost, sledenje nameri, kritično razmišljanje itn.

Sistem izobraževanja in usposabljanja, predvsem pa kadrovska politika, mora dopuščati tako imenovane dobronamerne napake, saj s tem spodbuja pobudo pri podrejenih in pripravljenost na akcijo, predvsem pa s tem krepi zaupanje podrejenih v nadrejene. Podrejeni morajo imeti občutek, da so napake, iz katerih se učijo, dovoljene in da jih nadrejeni v tem podpirajo in ščitijo.

\section{TEHNOLOGIJA IN POVELJEVANJE Z NAMERO}

Tehnologija je odraz temeljnih predpostavk in prepričanja družbe (Shamir, 2011, str. 168). Sodobna informacijska tehnologija ponuja veliko možnosti, vojaška informacijska tehnologija pa je obljubljala, da do dvignila Clausewitzevo »meglo vojne« in bo poveljujočim omogočila popoln vpogled v stanje na bojišču. Vojska ZDA je vložila ogromna sredstva v svoje digitalne divizije, a se je izkazalo, da tehnologija ni izpolnila pričakovanj. Mnogi so trdili, da bo sodobna informacijska 
tehnologija povzročila, da poveljevanje z namero ne bo več potrebno in bo rešila vse težave s frikcijo pri vodenju in poveljevanju v vojni in kriznih razmerah. Izkazalo pa se je ravno nasprotno. Uvajanje sodobne tehnologije je vodilo v poplavo informacij in informacijsko preobremenjenost ter tako imenovani sindrom plazma zaslonov. Zaradi informacijske preobremenjenosti poveljujoči niso več sposobni sprejemati racionalnih odločitev, projekcije stanj na zaslonih pa poveljujoče silijo $\mathrm{v}$ to, da ostajajo v štabih, daleč stran od dogajanja in brez zagotovila, da je to, kar gledajo na zaslonu, resnično stanje. Od poveljujočih na nižjih taktičnih ravneh se pričakuje, da bodo redno in sproti posodabljali informacije na informacijski tehnologiji, kar pa jih odvrača od ukvarjanja s situacijo, v kateri so se znašli. Višje nadrejeni se $\mathrm{z}$ informacijsko tehnologijo in različnimi droni vmešavajo $\mathrm{v}$ odločitve, ki bi jih morali sprejemati podrejeni oziroma se odločajo namesto njih. Vse to vodi $\mathrm{v}$ mikromenedžment, $v$ katerem je zaupanje med nadrejenimi in podrejenimi porušeno, pobude ni in napake so nedopustne.

Tudi uporaba zgolj tehnologije, ki spremlja lastne sile, tako imenovani blue force tracker, prinaša omejitve pri poveljevanju $\mathrm{z}$ namero, saj sili nadrejene $\mathrm{v}$ sinhronizacijo lastnih sil, pri čemer pa ubija pobudo in pripravljenost na akcijo pri podrejenih. Večkrat izpostavljen primer teh težav je operacija Puščavski vihar leta 1991, ki je v širši javnosti sicer veljala za šolsko izvedbo manevrske operacije, v resnici pa je zaradi nenehne potrebe po sinhronizaciji omogočila glavnini iraških sil (Republikanski gardi) umik brez resnejših posledic. Zavezniki so se bolj ukvarjali s sinhronizacijo lastnih sil, svojimi levimi in desnimi, kot pa z nasprotnikom.

Sodobna tehnologija vodenih projektilov povzroča preferenco ognja na račun manevra. Poveljujoči se namreč v strahu pred »nepotrebnimi« izgubami raje zatekajo $\mathrm{k}$ uporabi minometnega, artilerijskega in letalskega ognja, kot pa k napadalnemu manevru in prevzemanju pobude. Seveda je ta težava manjša v oboroženih silah, v katerih takšne tehnologije nimajo.

V povezavi tehnologije s konceptom poveljevanja z namero ne gre toliko za to, kako dobro tehnologijo imajo posamezne strani, temveč, kako jo bodo uporabile v boju. Ne smemo pozabiti, da so imeli Francozi in Britanci na začetku druge svetovne vojne več tankov in boljše kot Nemci ter na splošno tudi boljšo opremo, pa so bili kljub temu na zahodnem bojišču odločilno premagani.

\section{POVELJEVANJE Z NAMERO IN SLOVENSKA VOJSKA}

Doktrina vodenja in poveljevanja v SV, kot je formalno zapisana v Vojaški doktrini, $\mathrm{v}$ resnici povzema principe poveljevanja z namero (Furlan, 2006, str. 63):

Poveljevanje $v$ Slovenski vojski temelji na pravočasnem odločanju, jasnem razumevanju namere nadrejenega, sposobnosti podrejenih, da namere uresničijo, ter na poveljnikovi sposobnosti, da si predstavlja izvedbo načrta od začetka do konca. Pristop $k$ poveljevanju na podlagi poslanstva spodbuja decentralizirano 
poveljevanje, svobodo in hitrost delovanja ter iniciativo, vendar tudi dosledno upoštevanje usmeritev in navodil nadrejenega poveljnika. Za takšen pristop je pomembno, da poveljnik zagotovi, da podrejeni razumejo njegovo namero ter svoje poslanstvo in vlogo v strateškem, operativnem in taktičnem smislu. Razumeti morajo, kakšen učinek je treba doseči, in razloge, zakaj je to potrebno. Podrejeni morajo imeti jasno določeno poslanstvo, čas in prostor ter dovolj sil in sredstev za uresničitev poslanstva. $V$ izvedbi poveljnik $v$ čim manjši meri uporablja kontrolo in po nepotrebnem ne ovira svobode delovanja podrejenih poveljnikov. Ti sami odločajo, kako na najboljši način uresničiti poslanstvo enot, ki jim poveljujejo.

Vojaška doktrina SV torej natančno povzema principe auftragstaktik, pri čemer pa doktrina uporablja izraz poveljevanje na podlagi poslanstva, ki je, kot že rečeno, bližji anglo-ameriškemu izrazu mission command kot pruskemu auftragstaktik. ${ }^{6} \mathrm{SV}$ je prevzela tudi tehniko pisanja in izdajanja ukazov skladno z metodologijo, ki jo predpisuje Nato in ustreza metodologiji poveljevanja z namero.

Kljub temu je SV daleč od koncepta poveljevanja z namero, saj so že ukazi običajno izredno podrobni in obsežni, kar je v popolnem nasprotju z načeli takšnega poveljevanja. ${ }^{7}$ Morda bi bila $\mathrm{v}$ luči koncepta poveljevanja $\mathrm{z}$ namero zanimiva analiza vodenja in poveljevanja v slovenski Teritorialni obrambi leta 1991, vendar bi presegla okvire tega članka. Verjamem, da bi pokazala kar nekaj elementov poveljevanja z namero, a kljub temu na splošno ne bi mogli govoriti o tem, da je Teritorialna obramba uporabljala takšno poveljevanje. Njen poveljniški kader je bil namreč šolan po principih direktivnega vodenja. Enote so sestavljali večinoma rezervisti, ki niso bili vrhunsko usposobljeni, njihovi odnosi pa so temeljili bolj na osebnih poznanstvih kot na profesionalnih kompetencah. Enote se, z redkimi izjemami, tudi niso obsežno usposabljale, zato se postavlja tudi vprašanje zaupanja med nadrejenimi in podrejenimi. Na vsa ta vprašanja bi morala odgovoriti podrobnejša analiza dogajanja med osamosvojitveno vojno.

Nesporno pa je, da se bo SV skoraj nujno znašla v položaju, ko bo številčno ali tehnično šibkejša od svojih nasprotnikov in bo morala poiskati načine, kako te pomanjkljivosti ustrezno izravnati. Trdim, da to lahko stori s prevzemanjem iniciativnosti in disciplinirano napadalnostjo, ki jo omogoča poveljevanje z namero.

V operacijah v podporo miru in protiuporniških operacijah SV sodeluje oziroma bo sodelovala z manjšimi taktičnimi enotami na ravni voda ali čete in izjemoma za krajše obdobje tudi z bataljonsko bojno skupino. Pri tem so navadno poveljujoči teh enot

\footnotetext{
Razlika se bo komu zdela nepomembna, sam pa menim, da je ključna. V doktrini auftragstaktik je namera nadrejenega pomembnejša od dodeljenega poslanstva. Kot že rečeno, je v izvirni doktrini podrejenemu celo dovoljeno neizvrševanje poslanstva, če je kljub temu izpolnjena namera nadrejenega.

Kot ilustracijo lahko navedem, da je denimo ukaz pruskega generalštaba v vojni z Avstrijo leta 1866 obsegal vsega pet strani, kar je danes ob vsej tehnologiji skoraj nepredstavljivo v vseh zahodnih vojskah. Moltkeja so poleg tega v vojni s Francijo leta 1871 mnogi obtoževali lenuharjenja in neaktivnosti, saj je le redko in samo $v$ izjemnih primerih posredoval pri podrejenih, pač pa jim je pustil popolno svobodo delovanja, dokler je menil, da sledijo ciljem vojne.
} 
več sto ali tisoč kilometrov oddaljeni od svojih neposredno nadrejenih in ne poznajo podrobno vseh razmer na območju delovanja enot. Poleg tega gre v teh operacijah za delovanje znotraj koalicijskih si, pri katerem so poveljujoči enotam SV soočeni z dvojno linijo vodenja in poveljevanja - koalicijsko in nacionalno. Poveljujoči mora imeti $\mathrm{v}$ teh razmerah jasno predstavo o nameri nadrejenih in holistični pregled razmer na območju delovanja. Pobuda je v takih razmerah ključna, pri čemer pa ne gre samo za pripravljenost na akcijo, temveč tudi za zavedanje, kdaj ne delovati.

Za SV velja večina omejitev, ki veljajo tudi za druge oborožene sile zahodnega sveta, ko skušajo uvesti poveljevanje z namero v svoje delovanje. Če ga bo želela uporabiti kot doktrino vodenja in poveljevanja, bo morala poiskati rešitve za prepad med civilno družbo, iz katere prihajajo njeni pripadniki, in vrednostnim sistemom, ki ga zahteva poveljevanje z namero. Pri tem ne gre za to, da eno izključuje drugo, temveč za to, da se najde ustrezno ravnovesje, kar je naloga sistema izobraževanja in usposabljanja ter kadrovske politike. Povečati bo treba ugled SV, ki je primerjalno gledano glede na druge uniformirane poklice dokaj dober. Vendar pa ne zagotavlja pritoka ustreznega kadra, saj vojaški poklic po privlačnosti zaostaja, ne le za zdravniki in pravniki, temveč tudi za drugimi poklici, kot je na primer policijski inšpektor (Bebler, 2005, str. 94). To ugotavljajo tudi raziskovalci na Fakulteti za družbene vede v svojih raziskavah o odnosu slovenske mladine do vojaškega poklica - »/.../ vojska da, toda brez mene prosim« (Malešič, 2006, str. 167-168). Civilno-vojaški odnosi se bodo morali dvigniti na novo raven, na kateri bo Slovenski vojski priznana profesionalna avtonomija, ki pa si jo mora ta seveda najprej zaslužiti z izkazanimi kompetencami. Vse to bi moralo dati podlago za razvoj ustrezne vojaške kulture, ki bi podpirala poveljevanje $\mathrm{z}$ namero.

Sistem izobraževanja in usposabljanja mora hkrati zagotoviti poznavanje doktrine, profesionalnega jezika ter pisanja in interpretacije namere, prav tako mora bodoče častnike na vseh ravneh usposabljati za prevzemanje nalog nadrejenih. Poskrbeti pa mora tudi za poenotenje proceduralnega znanja štabnih procesov načrtovanja in odločanja. Kako to storiti? Predvsem je treba v sistem izobraževanja in usposabljanja uvesti selekcijske kriterije, ki bodo dovolj restriktivni, da bodo spodbujali kritično razmišljanje. To pomeni, da na šolanje niso sprejeti vsi po vrsti, temveč le tisti, ki so izkazano sposobni ustrezne ravni kritičnega razmišljanja. Sedanji sistem, v katerem so sprejeti vsi in vsi tudi uspešno opravijo vojaškostrokovno izobraževanje, je uničujoč za poveljevanje z namero. Ne gre za to, da se komur koli preprečuje vstop v sistem izobraževanja, temveč za to, da se za tiste, ki so prisotni, ustvari okolje, v katerem bodo lahko intelektualno in profesionalno napredovali. Nadalje mora sistem izobraževanja in usposabljanja zagotoviti kompetentne inštruktorje, ki bodo hkrati dobri učitelji oziroma predavatelji. Njihova naloga mora biti predvsem razvijati sposobnost kritičnega razmišljanja v okviru vojaške doktrine. Njihov cilj ni, da povedo, kaj je prav in kaj narobe, ampak, da razvijajo posameznikove analitične, taktične, voditeljske, poveljniške in druge lastnosti, ki so zaželene. To ne pomeni, da so inštruktorji lahko le vojaške osebe, daleč od tega. Celo zaželeno je, da so to tudi civilisti z ustreznimi kompetencami za posredovanje snovi, za katero so zadolženi. 
Vsekakor pa se moramo odmakniti od trenutnega stanja, v katerem so učitelji (inštruktorji, predavatelji) v sistemu izobraževanja in usposabljanja predvsem zaradi teritorialnega načela (živijo nekje blizu).

Toda za poveljevanje $\mathrm{z}$ namero je ravno toliko kot sistem izobraževanja in usposabljanja pomembno tudi, kaj se dogaja $\mathrm{v}$ enotah in poveljstvih. Ce se tam nadrejeni ne ukvarjajo s profesionalnim razvojem svojih podrejenih, je trud v sistemu izobraževanja in usposabljanja zaman.

Vsekakor pa je kadrovska politika, temelječa na profesionalnih kompetencah, tista, ki edina zagotavlja medsebojno zaupanje nadrejenih in podrejenih, kar je temeljni pogoj za delovanje poveljevanja $\mathrm{z}$ namero. V povezavi s sistemom izobraževanja in usposabljanja mora kadrovska politika zagotoviti, da je eden izmed pogojev za zasedanje poveljniške dolžnosti določene ravni poučevanje na vojaški šoli ustrezne nižje ravni - poveljniki polkov bi tako na primer morali prej poučevati na štabnem tečaju (poveljnike čet). Poleg tega pa bi morala kadrovska politika z ocenjevanjem v sistemu kariernega razvoja posameznika spodbujati k sprejemanju vrednot, želenih za uresničevanje doktrine poveljevanja z namero. Kar poenostavljeno pomeni, da bi moral ocenjevalni list službene ocene ustrezati zahtevam poveljevanja z namero.

SV se ravno tako spopada z izzivi sodobne tehnologije, predvsem informacijske. Je pa tehnologija tesno povezana s finančnimi sredstvi, ki so na voljo, zato je tehten premislek nujen. Eksperimentiranje z novo ali nepreizkušeno tehnologijo si lahko privoščijo veliki in bogati, za SV pa bi bilo primernejše uvajanje uveljavljenih tehnologij, ki preizkušeno delujejo, čeprav so kako generacijo starejše. Informacijska tehnologija je nedvomno bojni multiplikator, toda SV bo morala biti pozorna na že omenjene pasti mikrovodenja, informacijske preobremenjenosti in poveljevanja prek plazma zaslonov. Predvsem pa se mora častniški zbor SV zavedati, da tehnologija ni čarobni prah, ki bo rešil težave, ki jih povzročajo neustrezna organizacijska kultura, profesionalna nekompetentnost ter vodenje in poveljevanje. Prej nasprotno, samo še povečevala jih bo, kot bi jih tudi, če bi bilo vse na ustrezni profesionalni ravni.

Sklep Poveljevanje z namero je doktrina, ki omogoča številčno in tehnično šibkejšemu, da $\mathrm{z}$ izkoriščanjem majhnih oziroma trenutnih priložnosti vstopi $\mathrm{v}$ nasprotnikov cikel odločanja, za kar pa sta nujna prevzemanje pobud in pripravljenost na akcijo pod pogojem doktrinarne poenotenosti in medsebojnega zaupanja ter ob ustrezni organizacijski kulturi.

SV bo morala poiskati načine, ki ji bodo v spopadu z nasprotnikom, v katerem koli tipu operacije, prinesli želene rezultate. Ob tem da bo, kljub temu da je del zavezništva, najverjetneje vedno številčno in tehnično $\mathrm{v}$ podrejenem položaju. Poveljevanje z namero je vsekakor doktrina, ki bi jo v tem smislu veljalo natančneje proučiti in uvesti $v \mathrm{SV}$. 
SV bi s poveljevanjem z namero pridobila večjo hitrost in kakovost odzivanja na nastale situacije, tako na tradicionalnem kot postmodernem bojišču, boljši status vojaškega poklica v družbi, več zaupanja med nadrejenimi in podrejenimi, manjše izgube zaradi pasivnosti idr.

Trdim, da poveljevanje z namero ne bi imelo negativnih posledic za SV. Še več, trdim celo, da je edina možnost zanjo. Alternativa je namreč okoren in počasen sitem direktivnega vodenja, s katerim zmagaš, če prevladuješ v moštvu in opremi ter globini, ki ti dajejo čas in prostor za manever. Ne vidim, kako bi se Slovenija in SV lahko znašli v tem položaju v odnosu do morebitnih nasprotnikov.

Uveljavitev poveljevanja z namero v Slovenski vojski nikakor ne bi zahtevala milijonov evrov, niti več sto tisoč, pač pa spremembo klime in kulture organizacije. Za to pa bi potrebovali vsaj delne spremembe tudi v celotni družbi in njenem gledanju na SV. To niso spremembe, ki bi lahko nastale čez noč, ampak zahtevajo leta trdega dela. Hkrati pa niso tako nemogoče, kot se morda zdi. SV bi zrelost in pripravljenost na poveljevanje z namero pokazala že s tem, da bi sama sprožila procese, ki bi vodili v ustrezno organizacijsko kulturo, in dialog s civilno družbo. Ne da bi čakala, da to namesto nje stori kdo drug, na primer politika. Samo začeti je treba in vztrajati.

Literatura
1. Banko, A., 2009. Podoba Slovenske vojske v očeh mladih (diplomsko delo). Ljubljana: FDV.

2. Bebler, A., 2005. Sodobno vojaštvo in družba. Ljubljana: FDV.

3. Bucholz, A., 2001. Moltke and the German Wars, 1864-1871. New York: Palgrave.

4. Condell, B., in Zabecki, D. T., 2009. On the German Art of War, Truppenfuhrung, German Army manual for unit command in World War II. Mechanicsburg: Stackpole Books.

5. Craig, G. A., 1964. The Politics of the Prussian Army 1640-1945. London: Oxford University Press.

6. Furlan, B. (in drugi), 2006. Vojaška doktrina. Ljubljana: Defensor, d. o. o.

7. Guthrie, T., 2012. Mission Command: Do we have the stomach for what is really required. http://www.ausa.org/publications/armymagazine/archive/2012/06/Documents/ FC_Guthrie_0612.pdf

8. Huges, D. J., 1993. Moltke on the art of war, Selected writings. New York: Ballantine books.

9. Malešič. M., 2006. Varnost v postmoderni družbi. Ljubljana: FDV.

10. Moscos, C. C., 2000. The Postmodern Military. New York: Oxford University Press.

11. Murray, N., 2014. The role of professional military education in Mission Command. Joint Force Quaterly, 72-1. http://www.dtic.mil/doctrine/jfq/jfq-72.pdf

12. Nelsen, J. T. II, 1987. Auftragstaktik: A Case for Decentralized Battle. US Army War College Carlisle,PA.

13. Parker, G., 2009. Cambridge Illustrated History of Warfare, The Triumph of the West, Revised and Updated. New York: Cambridge University Press.

14. Rijavec, M., 2013. Poveljevanje z namero ali Mission Command. revija Slovenska vojska (informativno glasilo Ministrstva za Obrambo).

15. Shamir, E., 2011. Transforming Command; the pursuit of mission command in the U.S., British, and Israeli armies. California: Stanford University Press. 
16. Vandergriff, D. E., 2011. One step forward, two steps back: Mission Command versus the Army Personnel System. http://www.ausa.org/publications/ilw/Documents/LWP\%20 $84 \% 20$ Vandergriff_web\%20(2).pdf

17. Wright, D. P., 2013. 16 Cases of Mission Command. Fort Leawenworth, Kansas: Combat Studies Institute Press.

18. http://www.benning.army.mil/mssp/Mission\%20Command/ 